\title{
Jurist-Diction
}

Volume 4 No. 5 September 202

\section{Keterangan Saksi dengan Gangguan Jiwa Sebagai Alat Bukti di Pengadilan}

\author{
Put Fui Syafira Basuki \\ putfuisyafir@gmail.com \\ Universitas Airlangga
}

\begin{abstract}
How to cite:
Put Fui Syafira Basuki, 'Keterangan Saksi dengan Gangguan Jiwa Sebagai Alat Bukti di Pengadilan' (2021) Vol. 4 No. 5 Jurist-Diction.

Histori artikel:

Submit 15 Juli 2021;

Diterima 15 Agustus 2021;

Diterbitkan 1 September 2021.

DOI:

10.20473/jd.v4i5.29827

p-ISSN: $2721-8392$

e-ISSN: 2655-8297
\end{abstract}

\section{Abstract}

Witness testimony is evidence tool in the first sequence in the Criminal Procedure Code (KUHAP) so it can be said there is no criminal case which escapes from the proof of witness testimony. The legal requirement for a witness's statement is when a witness takes an oath. However, in article 171 letter $b$ of the Criminal Procedure Code (KUHAP) states that a person may give testimony without swearing, that is, a person who has memory loss or mental illness, although sometimes his memory is back. In psychology is referred to psychopaat, but the information given cannot be justified perfectly and his information is only used as a guide or additional legal evidence tool as long as it is compatible with legal evidence tool. This study uses the typology of doctrinal research with a legislation approach, conceptual approach, and case approach. Witness testimony given without the oath is considered not a valid evidence but is used as an adjunct to perfect the strength of legal evidence tool because it can strengthen the judge's conviction.

Keywords: Evidence Tool; Witnesses; Mental Disorder; Responsibility.

\section{Abstrak}

Keterangan saksi merupakan alat bukti pada urutan pertama dalam KUHAP sehingga dapat dikatakan bahwa tiada suatu perkara pidana yang luput dari pembuktian keterangan saksi. Syarat sah keterangan saksi adalah ketika seorang saksi mengucapkan sumpah. Namun pada pasal 171 huruf b KUHAP menyatakan bahwa seseorang boleh memberikan keterangan tanpa sumpah yaitu orang yang mengalami sakit ingatan atau sakit jiwa meskipun kadang-kadang ingatannya kembali dalam ilmu penyakit jiwa disebut dengan psychopaat, tetapi keterangan yang diberikan tidak dapat dipertanggungjawabkan secara sempurna dan keterangannya hanya dipakai sebagai petunjuk atau tambahan alat bukti sah asalkan berkesuaian dengan alat bukti sah. Penelitian ini menggunakan tipologi penelitian doktrinal dengan pendekatan perundang-undangan, pendekatan konseptual, dan pendekatan kasus. Keterangan saksi yang diberikan tanpa sumpah dinilai bukan merupakan alat bukti yang sah namun digunakan sebagai tambahan untuk menyempurnakan kekuatan pembuktian alat bukti yang sah karena dapat menguatkan keyakinan hakim.

Kata Kunci: Alat Bukti; Saksi; Gangguan Jiwa; Tanggungjawab.

Copyright $(\subset) 2021$ Put Fui Syafira Basuki 


\section{Pendahuluan}

Pembuktian merupakan hal yang sangat penting dalam proses pemeriksaan di sidang pengadilan, khususnya dalam perkara pidana karena ditujukan untuk mencari, menggali dan menemukan kebenaran materiil yaitu kebenaran yang hakiki atau yang sebenar-benarnya berdasarkan fakta hukum. Hukum acara pidana di Indonesia menganut sistem pembuktian menurut Undang-Undang secara negatif (negatief wettelijke bewijs theorie) yaitu dalam pembuktian hukum acara pidana sekurangkurangnya dua alat bukti ditambah dengan keyakinan hakim. ${ }^{1}$ Alat bukti keterangan saksi merupakan alat bukti yang terletak pada urutan pertama dalam pasal 184 ayat (1) KUHAP sehingga dapat dikatakan bahwa tidak mungkin ada suatu perkara pidana yang luput dari pembuktian keterangan saksi. ${ }^{2}$ Dalam persidangan, seorang korban apabila ia masih hidup dan dalam keadaan yang memungkinkan dapat dihadirkan sebagai saksi berdasarkan pasal 160 ayat (1) huruf b KUHAP bahwa: “dalam pemeriksaan di sidang pengadilan yang pertama didengar keterangannya adalah korban yang menjadi saksi”.

Semakin maraknya kejahatan dengan sasaran korban yang bisa berasal dari kalangan apa saja, tidak menutup kemungkinan orang dengan gangguan jiwa yang secara fisik dan psikis lebih lemah dari orang normal menjadi sasaran yang sesuai untuk tindak kriminal. Dikarenakan orang dengan gangguan jiwa berpotensi menjadi korban dalam tindak kejahatan dan beranjak dari pasal 171 huruf b KUHAP maka memungkinkan orang yang sakit ingatannya atau sakit jiwa untuk dihadirkan dalam persidangan guna memberikan kesaksian atas peristiwa yang dilihat, didengar dan dialami sendiri guna kepentingan penyidikan, penuntutan dan peradilan. Namun berdasarkan pasal 185 ayat (7) KUHAP keterangan saksi yang tidak disumpah apabila keterangan itu sesuai dengan keterangan dari saksi yang disumpah dapat digunakan sebagai tambahan alat bukti sah yang lain.

${ }^{1}$ Tolib Effendi, Dasar Dasar Hukum Acara Pidana Perkembangan dan Pembaharuan di Indonesia (2014).[171].

${ }^{2}$ M. Yahya Harahap, Pembahasan Permasalahan dan Penerapan Kitab Hukum Acara Pidana, Pemeriksaan Sidang Pengadilan, Banding, Kasasi, dan Peninjauan Kembali (2002).[287]. 
Dalam fakta pembuktian suatu tindak pidana, tidak semua saksi yang dihadirkan dan memberikan keterangan adalah orang normal atau orang waras. Suatu kasus pernah terjadi dalam kaitannya dengan orang gangguan jiwa sebagai saksi korban dalam persidangan, kasus ini telah diputus perkara pada Putusan Nomor 190/Pid.b/2012/PN.Olm. Dalam putusan tersebut didapatkan fakta bahwa terdakwa mencabuli anak tirinya yang diketahui oleh terdakwa adalah orang dengan gangguan mental sejak kecil namun terdakwa tetap melakukannya. Dalam pertimbangannya, hakim mengatakan bahwa gangguan mental atau cacat mental dapat dikategorikan sebagai "tidak berdaya" dalam kemampuan akan pendekatan yang wajar secara fisik sebagaimana dalam keadaan sehat, tetapi tidak berdaya dalam akal budi. ${ }^{3}$ Dalam persidangan guna menguatkan dalil dakwaan, Penuntut Umum mengajukan saksi Asri Delila Uas yang merupakan korban dengan tidak diambil sumpahnya memberikan kesaksian dalam persidangan. Dalam keterangan saksi lainnya yaitu Yonathan Ataupah yang merupakan saksi yang melihat sendiri kejadian tersebut, memberikan keterangan bahwa korban, Asri Delila Uas menderita gangguan jiwa sejak lahir.Dalam kasus ini, saksi Asri Delila Uas tidak termasuk dalam kategori yang tidak dapat didengar keterangannya sebagai saksi berdasarkan pasal 168 KUHAP. Lebih lanjut dalam pasal 171 huruf b KUHAP dinyatakan bahwa orang yang sakit ingatannya atau sakit jiwa meskipun ingatannya baik kembali boleh diperiksa untuk memberikan keterangan tanpa janji atau sumpah. Keterangan Saksi Asri Delila Uas dapat diakui sebagai saksi korban.

Contoh kasus kedua. Putusan Nomor 533/Pid.Sus/2015/PT-MDN (banding dari Putusan Nomor 1148/Pid.Sus/2015/PN-MDN). Kasus perbuatan kekerasan psikis dalam lingkup rumah tangga.Saksi korban merasa diterlantarkan dan mengalami kekerasan psikis. Berdasarkan Visum et Repertum Psycriatricum No. 49/ SK/VISUM/XII/2014 dari Rumah Sakit Umum DR. Pirngadi Medan menyimpulkan saksi korban mengalami gangguan episode berat. Perbuatan terdakwa diatur dan

\footnotetext{
${ }^{3}$ Tri Jata Ayu Pramesti, 'Sanksi Bagi yang Mencabuli Penderita Gangguan Mental' (Hukum Online,2014) <https://www.hukumonline.com/klinik/detail/ulasan/lt548c6c128c014/sanksi-bagiyang-mencabuli-penderita-gangguan-mental/>, dikunjungi pada 3-08-2019.
} 
diancam pidana pada pasal 49 huruf a jo pasal (9) ayat 1 UU RI No 23 tahun 2004 Tentang Penghapusan Kekerasan Dalam Rumah Tangga.

Bunyi pasal 171 huruf b KUHAP yang menyatakan orang sakit ingatan atau sakit jiwa meskipun kadang ingatannya baik kembali boleh dijadikan saksi dalam persidangan dengan tidak disumpah, menimbulkan sebuah kerancuan. Dimana diketahui bahwa penyakit jiwa dalam ilmu psikiatri ada banyak jenisnya dan penggunaan kata psychopaat pada penjelasan pasal 171 KUHAP ditinjau dari segi ilmu psikiatri.

Pasal 185 ayat (7) KUHAP dikatakan bahwa : "keterangan saksi yang tidak disumpah meskipun sesuai satu dengan yang lain tidak merupakan alat bukti namun apabila keterangan itu sesuai dengan keterangan dari saksi yang disumpah dapat digunakan sebagai tambahan alat bukti sah yang lain”. Pasal ini membuat kedudukan saksi dengan gangguan jiwa menjadi tidak jelas, dimana keterangan yang diberikan hanya sebagai alat bukti tambahan dari alat bukti yang sah dengan syarat keterangan itu sesuai dengan keterangan dari saksi yang diambil sumpahnya.

\section{Konsep Gangguan Jiwa}

Istilah yang digunakan dalam Pedoman Penggolongan dan Diagnosis Gangguan Jiwa, yang selanjutnya disebut PPDGJ di Indonesia adalah Gangguan jiwa atau Gangguan Mental (mental disorder), tidak mengenal istilah "penyakit jiwa" (mental disease/mental illness).

Orang Dengan Gangguan Jiwa dalam Undang-Undang Nomor 18 Tahun 2014 Tentang Kesehatan Jiwa Pasal 1 adalah orang yang mengalami gangguan dalam pikiran, perilaku, dan perasaan yang termanifestasi dalam bentuk sekumpulan gejala dan/atau perubahan perilaku yang bermakna, serta dapat menimbulkan penderitaan dan hambatan dalam menjalankan fungsi orang sebagai manusia.

Orang Dengan Gangguan Jiwa dalam Undang-Undang Nomor 8 Tahun 2016 Tentang Penyandang Disabilitas disebut dengan Penyandang disabilitas mental yaitu terganggunya fungsi pikir, emosi, dan perilaku, antara lain:

a. Psikososial diantaranya skizofrenia, bipolar, depresi, anxietas, dan gangguan kepribadian; dan 
b. Disabilitas perkembangan yang berpengaruh pada kemampuan interaksi sosial di antaranya autis dan hiperaktif..

\section{Klasifikasi Gangguan Jiwa}

Pedoman Penggolongan dan Diagnosis Gangguan Jiwa di Indonesia (yang selanjutnya disebut dengan PPDGJ III) menglasifikasikan gangguan jiwa meliputi 10 golongan :

1. F00-F09: Gangguan Mental Organik (termasuk Gangguan Mental Simtomatik);

2. F10-F19: Gangguan Mental dan Perilaku Akibat Zat Psikoaktif;

3. F20-F29 Skizofrenia, Gangguan Skizotipal, dan Gangguan Waham;

4. F30-F39 Gangguan Suasana Perasaan (Gangguan Afektif atau Mood);

5. F40-F48 Gangguan Neurotik, Gangguan Somatoform dan Gangguan Terkait Stres;

6. F50-F59 Sindrom Perilaku yang Berhubungan dengan Gangguan Psikologis dan Faktor Fisik;

7. F60-F69 Gangguan Kepribadian dan Perilaku Masa Dewasa;

8. F70-F79 Retardasi Mental;

9. F80-F89 Gangguan Perkembangan Psikologis;

10. F90-F98 Gangguan Perilaku dan Emosional dengan Onset Biasanya Pada Masa Kanak dan Remaja. ${ }^{4}$

Berdasarkan kesepuluh golongan gangguan jiwa menurut PPDGJ-III, digolongkan secara umum gangguan jiwa tersebut menjadi dua, yaitu gangguan jiwa psikosis dan gangguan jiwa non-psikosis:

a. gangguan jiwa psikosis, yang termasuk dalam golongan ini adalah:

a) golongan ke-1 (F00-F09) yaitu gangguan mental organik yang didalamnya termasuk gangguan mental simtomatik.

b) Golongan ke-3 (F20-F29) yaitu skizofrenia, gangguan skizotipal, gangguan waham.

c) Golongan ke-4 (F30-F39) yaitu gangguan perasaan (gangguan afektif atau mood).

d) Golongan ke-8 (F70-F79) yaitu retardasi mental.

b. gangguan jiwa non-psikosis, yang termasuk dalam golongan ini adalah:

a. Golongan ke-2 (F10-F19) yaitu gangguan mental dan perilaku akibat zat psikoaktif.

\footnotetext{
${ }^{4}$ Rusdi Maslim, Diagnosis Gangguan Jiwa,Rujukan Ringkas PPDGJ-III (2003).[22-135].
} 
b. Golongan ke-5 (F40-F48) yaitu gangguan neurotic, gangguan somatoform, dan gangguan terkait stress.

c. Golongan ke-6 (F50-F59) yaitu sindrom perilaku yang berhubungan dengan gangguan psikologis dan faktor fisik.

d. Golongan ke-7 (F60-F69) yaitu gangguan kepribadian dan perilaku masa dewasa.

e. Golongan ke-9 (F80-F89) yaitu gangguan perkembangan psikologis.

f. Golongan ke-10 (F90-F98) yaitu gangguan perilaku dan emosional dengan onset biasanya pada masa kanak dan remaja.

Berdasarkan kesepuluh golongan gangguan jiwa dikaitkan dengan kemampuan bertanggung jawab berdasarkan sudut pandang ilmu psikiatri, maka ada dua jenis kemampuan bertanggung jawab:

1. Tak Mampu Bertanggung Jawab, dikarenakan ketidakmampuan untuk memahami atau memilih sesuatu berdasarkan realita yang ada.

2. Bertanggung Jawab Penuh, selain dari golongan gangguan psikosis, sekalipun mereka menderita gangguan non psikosis, karena mereka terkadang bisa sadar seperti orang biasa, dan beberapa hanya tidak sadar saat gangguan yang mereka miliki sedang kambuh.

\section{Hak Penderita Gangguan Jiwa Sebagai Saksi}

Pada hakekatnya, setiap orang tanpa terkecuali memiliki hak yang sama sebagai warga Negara dan dihadapan hukum. Pasal 28 huruf H UUD 1945 menyatakan bahwa,"setiap orang berhak mendapat kemudahan dan perlakuan khusus untuk memperoleh kesempatan dan manfaat yang sama guna mencapai persamaan dan keadilan”. Pasal 17 Undang-Undang Nomor 39 Tahun 1999 tentang Hak Asasi Manusia, menyatakan bahwa : "Setiap orang, tanpa diskriminasi, berhak untuk memperoleh keadilan....". Pasal ini jelas menggunakan istilah setiap orang tanpa dipersyaratkan adanya keadaan dan kondisi tertentu dari subjek hukum yang dimaksud, maka dapat dikatakan bahwa dalam bab XA perihan Hak Asasi Manusia dalam UUD 1945 adanya pengalisifikasian yang terbagi hanya pada dua kelompok besar saja, melahirkan makna bahwa para penyandang disabilitas secara langsung maupun tidak, sudah termaktub didalamnya, dan pasal $28 \mathrm{H}$ ini mengatur 
perlindungan khusus bagi penyandang disabilitas. ${ }^{5}$

Hak keadilan dan perlindungan hukum untuk penyandang disabilitas sendiri telah dijamin dalam pasal 9 huruf a yaitu hak atas perlakuan yang sama dihadapan hukum dan pasal 9 huruf b yaitu hak diakui sebagai subjek hukum. Dalam pasal 30 ayat (1) menyatakan bahwa:

penegak hukum sebelum memeriksa penyandang disabilitas sebagai saksi, tersangka, terdakwa, atau korban wajib meminta pertimbangan atau saran dari dokter, psikolog, psikiater, atau tenaga ahli professional untuk mengetahui kondisi kesehatan dan kejiwaan penyandang disabilitas.

Dalam pasal 9 dikatakan bahwa penyandang disabilitas memiliki hak atas perlakuan yang sama dihadapan hukum dan diakui sebagai subjek hukum, maka dengan diakuinya penyandang disabilitas sebagai subjek hukum berarti menurut hukum ia mempunyai hak dan kewajiban sehingga memiliki kewenangan untuk bertindak dalam hukum dan dalam pasal 30 ayat (1) memperbolehkan penyandang disabilitas untuk menjadi saksi dengan terlebih dahulu meminta pertimbangan dan saran dari ahli yang professional untuk mengetahui kondisi kesehatan atau kejiwaan penyandang disabilitas, maka disini Undang-Undang Penyandang Disabilitas menjamin hak penyandang disabilitas dihadapan hukum dan hak asasi mereka sebagai manusia.

Selain pada pasal 30 Ayat (1) Undang-Undang Penyandang disabilitas yang diperbolehkan menjadi saksi, dalam praktek Kitab Undang-Undang Hukum Acara Pidana (KUHAP) juga memberikan hak yang sama di hadapan hukum untuk orang dengan gangguan jiwa dengan dibolehkannya orang dengan gangguan jiwa diperiksa untuk memberikan keterangan sebagai saksi namun dengan syarat tanpa sumpah, dalam Kitab Undang-Undang Hukum Acara Pidana pada Pasal 171 dikatakan bahwa:

Yang boleh diperiksa untuk memberi keterangan tanpa sumpah ialah:

a. Anak yang umurnya belum cukup lima belas tahun dan belum pernah kawin;

${ }^{5}$ RR.Putri A. Priamsari, 'Hukum yang Berkeadilan Bagi Penyandang Disabilitas' (2019) Jilid 48 No.2.[2]. 
b. Orang sakit ingatan atau sakit jiwa meskipun kadang-kadangingatannya baik kembali.

Berdasarkanistilahyang digunakanolehPPDGJyangmengatakan bahwa penyebutan yang benar adalah Gangguan jiwa atau Gangguan Mental (mental disorder) dan tidak mengenal istilah "penyakit jiwa" (mental disease/mental illness), dan dalam Undang-Undang Kesehatan Jiwa yang menyebut dengan Orang Dengan Gangguan Jiwa, maka selanjutnya dalam hal ini maksud Pasal ini diartikan sebagai gangguan jiwa. Lebih lanjut, dalam penjelasan Pasal 171 KUHAP, dikatakan bahwa:

“...orang yang sakit ingatan, sakit jiwa, sakit gila, meskipun hanya kadangkadang saja, yang dalam ilmu penyakit jiwa disebut dengan psychopaat, mereka ini tidak dapat dipertanggungjawabkan secara sempurna dalam hukum pidana maka mereka tidak dapat diambil sumpah atau janji dalam memberikan keterangan, karena itu keterangan mereka hanya dipakai sebagai petunjuk saja".

Penjelasan Pasal 171 KUHAP ini menggunakan kata psychopaat, sedangkan berdasarkan klasifikasi gangguan jiwa menurut PPDGJ-III, dari 10 (sepuluh) golongan yang termasuk didalamnya adalah jenis gangguan jiwa F00 sampai dengan F98 tidak ada penggunaan istilah psychopaat, namun beberapa sumber memberikan penjelasan yang pada intinya adalah gangguan kepribadian antisosial yang termasuk dalam golongan ke-tujuh yaitu F60-F69. Untuk penafsiran penyakit atau gangguan jiwa yang termasuk ke dalam Pasal 171 KUHAP ini, diambil ruhnya yaitu ketidakmampuan bertanggung jawabnya. Meskipun dalam ilmu psikiatri dikatakan bahwa psikopat tetap mempertanggung jawabkan perbuatannya karena ia termasuk dalam golongan non psikosis, namun pada pasal 171 KUHAP ini menekankan kepada maksud dari pembuat KUHAP yang lebih merujuk kepada orang sakit jiwa atau gangguan jiwa.

Disimpulkan bahwa pada pasal 171 KUHAP berdasarkan pembahasan hak yang diatur dalam beberapa beberapa peraturan perundang-undangan, pada pasal 30 Ayat (1) Undang-Undang Tentang Penyandang Disabilitas, Penyandang disabilitas diperbolehkan menjadi saksi, dalam praktek KUHAP juga memberikan hak yang sama di hadapan hukum untuk orang dengan gangguan jiwa dengan dibolehkannya orang dengan gangguan jiwa diperiksa untuk memberikan keterangan sebagai saksi 
namun dengan syarat tanpa sumpah, karena pada hakikatnya menjadi saksimerupakan perwujudan dari hak asasi manusia dan hak atas perlakuan yang sama dihadapan hukum, yang membedakan hanyalah kepada ketentuan sumpah untuk orang yang disebut Orang Dengan Gangguan Jiwa dalam Undang-Undang Kesehatan Jiwa dan penyandang disabilitas mental dalam Undang-Undang Penyandang Disabilitas saja yang tidak diambil sumpahnya saat memberikan keterangan di pengadilan atas dasar ketidakmampuannya bertanggungjawab diakibatkan pertimbangan pada pasal 30 ayat (1) UU penyandang disabilitas bahwa penegak hukum sebelum memeriksa penyandang disabilitas sebagai saksi wajib meminta pertimbangan dari ahli untuk mengetahui kondisi kesehatan dan kejiwaan penyandang disabilitas. Dalam hal ini untuk penyandang disabilitas selain penyandang disabilitas mental, tetap sah untuk diambil sumpahnya karena secara sadar mampu untuk bertanggungjawab atas kesaksian yang diberikan.

\section{Keabsahan Alat Bukti Keterangan Saksi Dari Penderita Gangguan Jiwa}

Hukum acara pidana di Indonesia menganut sistem pembuktian menurut Undang-undang secara negatif (negatief wettelijke bewijs theorie) yaitu dalam pembuktian hukum acara pidana sekurang-kurangnya dua alat bukti ditambah dengan keyakinan hakim. Hal ini tertuang dalam pasal 183 KUHAP menyatakan bahwa: "hakim tidak boleh menjatuhkan pidana kepada seorang kecuali apabila dengan sekurang-kurangnya dua alat bukti yang sah ia memperoleh keyakinan bahwa suatu tindak pidana benar-benar terjadi dan bahwa terdakwalah yang bersalah melakukannya". Pasal 183 KUHAP dipertegas dengan pasal 185 ayat (2) yang menyatakan bahwa:"keterangan seorang saksi saja tidak cukup untuk membuktikan bahwa terdakwa bersalah terhadap perbuatan yang didakwakan kepadanya". Asas ini biasa disebut dengan satu saksi tidak merupakan saksi (unus testis nullus testis). Dan pasal 189 ayat (4) yang menyatakan keterangan atau pengakuan terdakwa (confession by on accused) saja tidak cukup membuktikan kesalahan terdakwa.

Alat bukti yang sah berdasarkan pasal 184 ayat (1) KUHAP:

a. keterangan saksi; 
b. keterangan ahli;

c. surat;

d. petunjuk; dan

e. keterangan terdakwa.

Alat bukti keterangan saksi merupakan alat bukti yang terletak pada urutan pertama dalam pasal 184 ayat (1) KUHAP sehingga dapat dikatakan bahwa tiada suatu perkara pidana yang luput dari pembuktian keterangan saksi. Sangat pentingnya keberadaan saksi, maka dalam KUHAP diatur bahwa panggilan sebagai saksi merupakan kewajiban yang harus dipenuhi dan apabila menolak menjadi saksi, seseorang dapat dikenakan pidana berdasarkan ketentuan Undang-undang yang berlaku. Keterangan saksi berdasarkan pasal 1 angka 27 adalah "salah satu alat bukti dalam perkara pidana yang berupa keterangan dari saksi mengenai suatu peristiwa pidana yang ia dengar sendiri, ia lihat sendiri, dan ia alami sendiri dengan menyebut alasan dari pengetahuannya itu".

Pengertian saksi diperluas dengan adanya putusan Mahkamah Konstitusi nomor 65/PUU-VIII/2010 Tentang Pengujian Undang-Undang Nomor 8 Tahun 1981 Tentang Hukum Acara Pidana bahwa saksi termasuk orang yang dapat memberikan keterangan dalam rangka penyidikan, penuntutan, dan peradilan suatu tindak pidana yang tidak selalu ia dengar, liat dan alami sendiri yang keterangannya ada relevansinya dengan perkara pidana yang sedang diproses.

\section{Syarat-Syarat Kesaksian Sebagai Alat Bukti}

Keterangan seorang saksi akan bernilai sebagai alat bukti sah apabila syarat yang ada terpenuhi. Syarat tersebut sebagai berikut :

a. Syarat Objektif

1. Tidak boleh bersama-sama sebagai terdakwa, tercantum dalam pasal 168 KUHAP;

2. Tidak boleh ada hubungan keluarga, tercantum dalam pasal 168 KUHAP;

3. Mampu bertanggung jawab, yaitu berumur 15 tahun atau sudah pernah kawin atau tidak sakit ingatan. 
b. Syarat Formal:

1. Kesaksian saksi diucapkan dalam sidang pengadilan;

2. Kesaksian harus diucapkan dibawah sumpah atau janji;

3. Satu saksi bukanlah saksi (unus testis nullus testis) dengan pengecualian satu saksi dapat menjadi saksi manakala didukung alat bukti yang lain, misalnya keterangan terdakwa yang mengakui perbuatannya. ${ }^{6}$

c. Syarat Subyektif atau material:

1. Saksi menerangkan apa yang ia lihat, ia dengar dan ia alami sendiri;

2. Dasar-dasar atau alasan saksi tersebut melihat, mendengar dan mengalami sendiri sesuatu yang ia terangkan. ${ }^{7}$

\section{Keabsahan Keterangan Saksi yang Mengalami Gangguan Jiwa}

Pemeriksaan saksi ditentukan dalam pasal 160 ayat (1) huruf b KUHAP bahwa: "yang pertama didengar keterangannya adalah korban yang menjadi saksi”. Saksi, baik yang menguntungkan maupun memberatkan terdakwa yang tercantum dalam surat pelimpahan perkara dan/atau yang diminta oleh terdakwa atau penasehat hukum ataupun penuntut umum selama berlangsungnya persidangan atau sebelum dijatuhkannya putusan, hakim wajib mendengarkan keterangan saksi tersebut. ${ }^{8}$

Syarat sah keterangan seorang saksi adalah harus mengucapkan sumpah atau janji sebagaimana diatur dalam pasal 160 ayat (3) sebelum saksi memberikan keterangan, wajib mengucapkan sumpah atau janji yang dilakukan menurut cara agamanya masing-masing, lafal sumpah tersebut bahwa saksi akan memberikan keterangan yang sebenar-benarnya tiada lain daripada yang sebenarnya.

Lantas ketika saksi korban tersebut adalah orang yang ada pada pasal 171 mereka ini adalah saksi utama atau "kroon getuige" yang dikarenakan ketidak mampuannya untuk bertanggung jawab mengakibatkan ia tidak diambil sumpahnya. Maka pada pasal 185 ayat (7) nilai kekuatan pembuktian yang melekat

\footnotetext{
${ }^{6}$ Didik Endro Purwoleksono, Hukum Acara Pidana (2015).[114].

${ }^{7}$ ibid.

${ }^{8}$ Andi Hamzah, Pengantar Hukum Acara Pidana di Indonesia (Ghalia Indonesia 1987).[242].
} 
pada keterangan saksi yang dibacakan di sidang pengadilan setidaknya dapat disamakan dengan keterangan yang diberikan tanpa sumpah. Jadi, sifatnya tetap tidak merupakan alat bukti, tetapi nilai kekuatan pembuktian melekat padanya dimana keterangan tanpa disumpah dipergunakan untuk memperkuat keyakinan hakim maupun dapat bernilai sebagai tambahan alat bukti sah yang lain asalkan keterangan saksi yang dibacakan mempunyai kesesuaian dengan alat bukti sah tersebut dan alat bukti yang ada telah memenuhi batas minimum pembuktian yaitu dua alat bukti.

Saksi pada pasal 171 sekalipun merupakan saksi korban, keterangannya dinilai bukan merupakan alat bukti yang sah. Meskipun begitu keterangannya digunakan sebagai petunjuk. Apabila dikaitkan dengan pasal 161 ayat (2) dimana dikatakan bahwa keterangan seseorang yang tidak mau disumpah maka keterangannya merupakan keterangan yang dapat menguatkan keyakinan hakim, dengan pasal 169 ayat (2) dimana dikatakan bahwa tanpa persetujuan diperbolehkan memberikan keterangan tanpa disumpah dan pada penjelasan pasal 171 KUHAP yang mengatakan bahwa tidak dapat dipertanggungjawabkan secara sempurna dalam hukum pidana maka mereka tidak dapat diambil sumpahnya karena keterangan mereka hanya dipakai sebagai petunjuk saja.

Titik tolak untuk mengambil kesimpulan umum dalam hal ini ialah pasal 187 ayat (7) tanpa mengurangi ketentuan lain yang diatur dalam Pasal 161 ayat (2), maupun Pasal 169 ayat (2) dan penjelasan Pasal 171. Bertitik tolak dari ketentuanketentuan tersebut, secara umum dapat disimpulkan:

i. Semua keterangan saksi yang diberikan tanpa sumpah dinilai "bukan merupakan alat bukti yang sah". Walaupun keterangan yang diberikan tanpa sumpah itu saling bersesuaian dengan yang lain, sifatnya tetap "bukan merupakan alat bukti”,

ii. Tidak mempunyai nilai kekuatan pembuktian, Setiap keterangan tanpa sumpah, pada umumnya “tidak mempunyai nilai kekuatan pembuktian". Sifatnya saja pun bukan alat bukti yang sah, dengan sendirinya tidak mempunyai nilai kekuatan pembuktian. 
iii. Akan tetapi, “dapat” digunakan sebagai tambahan alat bukti yang sah. Sekalipun keterangan tanpa sumpah bukan merupakan alat bukti yang sah, dan juga tidak memiliki kekuatan pembuktian, pada umumnya keterangan "dapat" dipergunakan "sebagai tambahan" menyempurnakan kekuatan pembuktian alat bukti yang sah:

a. Dapat "menguatkan keyakinan hakim" seperti yang disebut pada pasal 16 ayat (2);

b. Dapat dipakai "sebagai petunjuk" seperti yang disebut dalam penjelasan pasal $171 .{ }^{9}$

Untuk mempergunakan keterangan tanpa disumpah baik untuk tambahan alat bukti yang sah maupun sebagai petunjuk untuk menguatkan keyakinan hakim harus dibarengi dengan:

1. Didahului oleh alat bukti yang sah yang terdapat dalam pasal 184 ayat (1) KUHAP;

2. Alat bukti yang ada telah berjumlah dua atau lebih alat bukti yang mana merupakan ketentuan alat bukti minimal berdasarkan pasal 183 KUHAP;

3. Terdapat kesesuaian antara keterangan saksi yang disumpah dengan yang tidak disumpah.

\section{Kesimpulan}

Saksi yang boleh diperiksa untuk memberikan keterangan tanpa disumpah berdasarkan pasal 171 huruf b KUHAP adalah orang sakit ingatan atau sakit jiwa meskipun kadang-kadang ingatannya kembali yang dalam ilmu penyakit jiwa disebut dengan psychopaat. Pedoman Penggolongan dan Diagnosis Gangguan Jiwa (PPDGJIII) di Indonesia menggunakan istilah Gangguan jiwa atau Gangguan Mental, bukan istilah penyakit jiwa, begitupun dengan Istilah psychopaattidak disebutkan namun digolongkan dalam gangguan kepribadian antisosial dalam golongan ke-tujuh yaitu

${ }^{9}$ Yahya Harahap, Pembahasan Permasalahan dan Penerapan Kitab Hukum Acara Pidana, Pemeriksaan Sidang Pengadilan, Banding, Kasasi, dan Peninjauan Kembali (2002).[293]. 
F60-F69. Dalam ilmu psikiatri psikopat mampu untuk bertanggung jawab penuh karena ia termasuk dalam golongan non psikosis, tetapi menekankan kepada maksud dari pembuat KUHAP maka dikategorikan tidak mampu bertanggung jawab tetapi tetap didengar keterangannyakarena pada hakikatnya menjadi saksi merupakan perwujudan dari hak asasi manusia dan hak atas perlakuan yang sama dihadapan hukum, yang membedakan hanyalah kepada ketentuan sumpah untuk orang yang disebut Orang Dengan Gangguan Jiwa dalam Undang-Undang Kesehatan Jiwa dan penyandang disabilitas mental dalam Undang-Undang Penyandang Disabilitas saja yang tidak diambil sumpahnya saat memberikan keterangan di pengadilan atas dasar pertimbangan dari ahli untuk mengetahui kondisi kesehatan dan kejiwaan penyandang disabilitas. Dalam hal ini untuk penyandang disabilitas selain penyandang disabilitas mental, tetap sah untuk diambil sumpahnya karena secara sadar mampu untuk bertanggungjawab atas kesaksian yang diberikan.

Saksi pada pasal 171 sekalipun merupakan saksi korban, keterangannya dinilai bukan merupakan alat bukti yang sah, meskipun begitu keterangannya digunakan sebagai petunjuk. Dapat dipergunakan sebagai tambahan alat bukti yang sah sekalipun keterangan tanpa sumpah bukan merupakan alat bukti yang sah dan juga tidak memiliki kekuatan pembuktian. Pada umumnya keterangan tersebut dapat dipergunakan sebagai tambahan untuk menyempurnakan kekuatan pembuktian alat bukti yang sah karena dapat menguatkan keyakinan hakim.

\section{Daftar Bacaan}

\section{Buku}

Andi Hamzah, Pengantar Hukum Acara Pidana di Indonesia (Ghalia Indonesia 1987).

Didik Endro Purwoleksono, Hukum Acara Pidana (Airlangga University Press 2015).

M. Yahya Harahap, Pembahasan Permasalahan dan Penerapan Kitab Hukum Acara Pidana, Pemeriksaan Sidang Pengadilan, Banding, Kasasi, dan Peninjauan Kembali (Sinar Grafika 2002).

Rusdi Maslim, Buku Saku Diagnosis Gangguan Jiwa,Rujukan Ringkas PPDGJIII, (PT Nuh Jaya 2003). 
Tolib Effendi, Dasar Dasar Hukum Acara Pidana Perkembangan dan Pembaharuan di Indonesia (Setara Press 2014).

\section{Laman}

Tri Jata Ayu Pramesti, 'Sanksi Bagi yang Mencabuli Penderita GangguanMental', (2014)<https://www.hukumonline.com/klinik/detail/ulasan/ 1t548c6c128c014/sanksi-bagi-yang-mencabuli-penderita-gangguan-mental/> dikunjungi pada 3-08- 2019.

\section{Jurnal}

RR.Putri A. Priamsari, 'Hukum yang Berkeadilan Bagi Penyandang Disabilitas' (2019) Jurnal Kejaksaan Negeri Temanggung.

\section{Perundang-undangan}

Undang-Undang Dasar Negara Republik Indonesia Tahun 1945.

Undang-Undang Republik Indonesia Nomor 8 Tahun 1981 Tentang Hukum Acara Pidana (Lembar Negara Nomor 76 Tahun 1981, Tambahan Lembar Negara Nomor 3209).

Undang-Undang Republik Indonesia Nomor 3 Tahun 1966 (Tambahan Lembar Negara Nomor 2805) juncto 18 Undang-Undang Nomor 36 Tahun 2014 Tentang Kesehatan Jiwa (Tambahan Lembar Negara Nomor 5571).

Undang-Undang Republik Indonesia Nomor 39 Tahun 1999 Tentang Hak Asasi Manusia (Lembar Negara Republik Indonesia Tahun 1999 Nomor 165, Tambahan Lembar Negara Republik Indonesia Nomor 3886).

Undang-Undang Republik Indonesia Nomor 36 Tahun 2009 (Tambahan Lembar Negara Nomor 5063) juncto Undang-Undang Nomor 36 Tahun 2014 Tentang Kesehatan (Tambahan Lembar Negara Nomor 5607).

Undang-Undang Republik Indonesia Nomor 8 Tahun 2016 Tentang Penyandang Disabilitas (Lembar Negara Republik Indonesia Tahun 2016 Nomor 69, Tambahan Lembar Negara Nomor 5871).

\section{Putusan Pengadilan}

Putusan pengadilan Negeri Oelemasi Nomor 190/Pid.b/2012/PN.Olm.

Putusan pengadilan Tinggi Medan Nomor:533/Pid.sus/2015/PT-MDN (Banding Putusan Pengadilan Negeri Medan Nomor:1148/Pid.Sus/2015/PN-MDN). 
1952 Put Fui: Keterangan Saksi Dengan...

--halaman ini sengaja dibiarkan kosong-- 